\title{
Environmental Regulation, Enterprises' Bargaining Power, and Enterprises' Total Factor Productivity: Evidence from China
}

\section{Shuwang Yang}

China University of Geosciences

Chao Wang ( $\nabla$ hnxyxxwangchao@163.com )

China University of Geosciences https://orcid.org/0000-0002-2298-8713

Hao Zhang

China University of Geosciences

Tingshuai Lu

China University of Geosciences

Yang Yi

China University of Geosciences

\section{Research Article}

Keywords: Environmental regulation, Total factor productivity, Enterprises' bargaining power, Moderating role, LP method, Heterogeneity analysis

Posted Date: June 28th, 2021

DOl: https://doi.org/10.21203/rs.3.rs-586149/v1

License: (1) This work is licensed under a Creative Commons Attribution 4.0 International License. Read Full License 


\section{Abstract}

The relationship between environmental regulation and enterprises' total factor productivity (TFP) has been a hot topic in the field of environmental economics, but the conclusions are still mixed. Employing a sample of 14,110 firm-year observations in China from 2010 to 2018, our research explores whether and when environmental regulation could trigger firms, to enhance TFP. The available evidence leads us to cautiously conclude that: 1) Environmental regulation notably improves enterprises' TFP, the conclusion still holds after a series of robustness tests. 2) Enterprises' bargaining power significantly weakens the influence of environmental regulation on enterprises' TFP. 3) Compared with non-state-owned enterprises and non-heavy-polluting industries, environmental regulation has a greater impact on state-owned enterprises and heavy-polluting industries; higher executive compensation does not motivate firms to improve TFP; compared with enterprises headquartered in non-provincial capital cities, environmental regulation has a greater impact on enterprises' TFP in provincial capital cities. Overall, the findings of our research are extremely relevant for the government, investor, and enterprise's manager, this paper provides micro-firm-level evidence for the Porter hypothesis in practice in China.

\section{Introduction}

Since the reform and opening up, China's rapid economic development has been accompanied by a series of environmental issues caused by the inefficient use of social resources, which has caused significant losses to people's lives and property safety (Chen et al. 2013a; Wang et al. 2021), and in response to the increasing environmental pollution, the Chinese government has issued a series of environmental regulatory measures (Chang et al. 2015). As the traditional development philosophy of pursuing economic growth has not changed, China's environmental issues remain serious (Jin et al. 2016), and China's environmental governance is featured by "campaign-style governance" (Chen et al. 2013b; He et al. 2016),[1] "soft implementation" (Du et al. 2014), and the existing governance effect is only reflected in the temporary improvement of the environment (Chen et al. 2013b). At present, China still regards economic development as its top priority, and faces the trade-off between high-quality economic development and environmental protection (Zheng and Chen 2020). Improving total factor productivity (TFP) is an important way for China's economy to shift from "extensive growth" to "intensive growth". To this end, the central government attaches great importance to TFP improvement, and the shift of China's economy from input-based growth to efficiency-based growth is imminent; the 2015 State Council Government Work Report for the first time makes TFP improvement an important goal for economic development.[2] At the same time, the report of the $19^{\text {th }}$ National Congress of the Communist Party of China clearly pointed out that we should "promote the reform of economic development quality, efficiency and power, and improve the TFP."[3]

Research on the impact of environmental regulation on TFP is abundant, but the academic community has not reached a consensus on the relationship between the two (Becker 2011; Yang et al. 2012; He et al. 2020). In China, the environmental regulation policies are generally formulated by the central government and are dominated by the command-and-control environmental regulation (Wang et al. 2015), while local 
government plays a leading role in the implementation of environmental regulation policies (Tang et al. 2018). Under China's environmental decentralization system and cadre evaluation system, local government officials tend to place more emphasis on economic development than on environmental performance in order to gain a greater promotion probability (Xu 2011). Therefore, local government possesses more discretion when implementing environmental regulation policies, which leads to the incomplete implementation of the central government's environmental regulation policies (Chang et al. 2015). One of the most important reasons is that enterprises bargain with local governments by virtue of their contribution to local governments' tax, employment rate and economic growth, so as to exempt from environmental regulation to a certain extent (Feng et al. 2020). As a typical example, in Jiaokou County, Lvliang City, Shanxi Province, Xinfa aluminum plant paid $85 \%$ of the local tax revenue at its peak, and by virtue of this strength the plant managed to escape three shutdown penalties from the Ministry of Environmental Protection. [4] And tax protection will exacerbate environmental pollution (Bai et al. 2019). Researches show that environmental regulation will lead to the decline of labor demand (Rivers 2013; Liu et al. 2017; Liu et al. 2021), limited by the employment rate brought by enterprises to local government, in order to maintain social stability, local government may weaken environmental regulation intensity. Therefore, when enterprises enter into regulatory capture, the enterprises with greater bargaining power can get more lenient environmental regulation, and the result is that environmental regulation policy lacks real implementation effect (Chang et al. 2015).

Against the backdrop, it is important to provide convincing evidence for the practice of Porter hypothesis in China. Herein, we focus on whether and when environmental regulation could enhance enterprises' TFP. To solve this issue, our study adopts a sample of 14,110 firm-year observations in China from 2010 to 2018 to study the casual effect of environmental regulation on enterprises' TFP, and further explores the moderating role of enterprises' bargaining power the casual effect. More deeply, this paper discusses the heterogeneity of casual effect from enterprise-, industry- and region-level. Our study finds that, environmental regulation notably enhances enterprises' TFP, enterprises' bargaining power weaken the positive relationship between environmental regulation and enterprises' TFP. The results of the heterogeneity analysis indicate that environmental regulation has a greater impact on enterprises' TFP for state-owned enterprises, enterprises with lower executive compensation, heavy-polluting industries, and enterprises headquartered in provincial capitals. The empirical results of this study can provide reference for the government to formulate reasonable environmental regulation policies.

Our paper adds value in the following ways. First, While there exists a large empirical studies on how environmental regulation affects TFP, most of them focus on the industry, city or provincial level (Wang et al. 2020; Hou et al. 2020; Xie et al. 2017). This paper provides new evidence for the applicability of Porter hypothesis in developing countries from the perspective of micro enterprises. Second, unfortunately, enterprises' bargaining power has not been paid enough attention by the academic circles, or only measure the bargaining power from a single aspect such as the total output of enterprises (Feng et al. 2020), which can't comprehensively reflect the bargaining behavior between enterprises and local government. This paper creatively measures enterprises' bargaining power from a more comprehensive perspective, and reveal the mystery of how enterprises' bargaining power affects the relationship between 
environmental regulation and enterprises' TFP. Third, drawing on the top literature in the field of environmental economics (Chen et al. 2018), the environmental regulation variables in this paper are derived from authoritative government documents, which can not only comprehensively reflect the government's environmental regulation intensity, but also effectively alleviate the endogenous problems.

The remainder of our research is organized as follows: Section 2 introduces research hypotheses; Section 3 is the research design, which introduces the research methods, including sample selection, data collection, model establishment and variable definition; Section 4 gives the empirical results and analysis; Section 5 summarizes the conclusions of our study and puts forward some managerial suggestions.

[1] A typical example is Olympic blue. To prepare for the 2008 Olympic Games, China adopted a number of radical measures to improve air quality, such as vehicle restrictions and factory shutdown. Chen, Jin, Kumar, and Shi (2013) found that these measures improved the API of Beijing during and after the games, but $60 \%$ of the effect faded away by the end of October 2009.

[2] Official document at: http://www.gov.cn/guowuyuan/2015-03/16/content_2835101.htm.

[3] Official document at: http://www.12371.cn/2017/10/27/ARTI1509103656574313.shtml.

[4] More details can be accessed at:

https://www.cenews.com.cn/opinion/201905/t20190510_898654.html.

\section{Research Hypotheses}

Environmental regulation, when improving environmental performance, inevitably affects activities such as resource reallocation, capital investment and technological innovation in the production process of firms (Albrizio et al. 2017), which in turn affects enterprises' TFP. On the one hand, enterprises that comply with environmental regulation are more likely to get preferential measures such as finance, tax, price and government procurement (Xu et al. 2020), which will provide essential guarantee for the growth of TFP. On the other hand, environmental regulation provides necessary external conditions for enterprises to improve production efficiency. Although environmental regulation may incur some "compliance costs" (Xie et al. 2017), moderate and strict environmental regulation can promote technological innovation, enhance firms' competitive strength and productivity, and thus partially or even fully compensate firms for the "compliance costs" incurred by environmental regulation. Enterprises' environmental protection behavior is more likely to bring good reputation to enterprises, and this kind of intangible asset will ultimately help to improve enterprise performance (Vanhamme et al. 2012; Li et al. 2019), so as to improve enterprise's TFP and achieve a win-win situation of environmental governance and enterprise profitability. Numerous studies (e.g., Porter and Linde 1995; Ai et al. 2020) have supported the notion that environmental regulation are more conductive to enterprise's TFP.

In light of the above-mentioned arguments, we put forward our first hypothesis:

Hypothesis 1: Environmental regulation will significantly improves enterprise's TFP. 
When the central government begins to tackle environmental issues with a heavy hand, local government rarely follows in lockstep (Child et al. 2007), and although the central government has fully recognized the importance of environmental protection, local government has not always given environmental governance an equally high priority (Wang et al. 2018). The reason for this is that under China's current cadre appraisal system and environmental territorial management system, the marginal effect of economic performance is much greater than that of environmental performance in the promotion process of local government officials (Jiang et al. 2020; Tang et al. 2021). Therefore, limited by the contribution of enterprises to local economic growth, in order to maximize the promotion probability, local government officials are justified in weakening environmental regulation. In addition, according to Porter hypothesis, environmental regulation can promote enterprise innovation and improve production efficiency. Due to the randomness of innovation activities (Noailly and Smeets 2015), large investment and long cycle (Ren et al. 2021), and the improvement of TFP takes a longer time to complete (Lanoie et al. 2008), thus enterprises are not willing to invest their limited capital in innovation activities with high uncertainty. Enterprises rely on their contribution to local government's employment rate, economic growth and tax revenue, and take it as a bargaining chip with local government to demand local government to weaken environmental regulation. In this case, local governments have strong incentives to become the "umbrella" of polluting enterprises. In order to obtain more tax sources, local government may be captured by enterprises and "open the back door" to polluting enterprises (Ran 2017). At the same time, enterprises lose the incentive of technological innovation, and enterprises' bargaining power will eventually have a negative impact on enterprises' TFP. Given the above-mentioned arguments, we propose our second hypothesis:

Hypothesis 2: Enterprises' bargaining power will weaken the positive relationship between environmental regulation and enterprises' TFP.

Fig. 1 depicts the conceptual framework based on the above arguments. The impact of environmental regulation on enterprises' TFP is the main line of this study. Along this line, our paper further explores the moderating effect of enterprises' bargaining power on the main effect. Further, this paper explores the moderating effects of firm ownership structure, executive compensation differences, firm pollution levels, and regional political constraints on the relationship between environmental regulation and enterprises' TFP.

\section{Research Design}

\section{Data and sample}

This paper selects Chinese listed companies from 2010-2018 as the initial sample. The above listed companies are also screened according to the following criteria: (1) listed companies with special treatment (ST/PT) and financial listed companies are eliminated; (2) insolvent listed companies, i.e. those whose debt ratio is already higher than $100 \%$, are eliminated; (3) listed companies that are merged and restructured are excluded; (4) those companies listed in the current year are excluded; (5) listed 
companies with incomplete data on certain indicators are excluded. Finally, 14,110 observations were obtained, involving 2,282 unique listed companies. To mitigate the influence of potential outliers, all continuous variables are winsored at the level of $1 \%$. The basic data of the dependent variables $(T F P)$ are from CSMAR database and calculated by LP method and OP method. The independent variables ( $E R$, $E R 2$ and $E R 3$ ) are constructed according to the frequency of environmental-related vocabulary and the proportion of words in environmental-related paragraphs in annual government work reports at the city level. In addition to regulatory capture from the China Research Data Service Platform (CNRDS), other firm-level data comes from the China Stock Market and Accounting Research (CSMAR) Database. The region-level data such as per capita GDP, industrial structure, population density, foreign direct investment and government science expenditure scale come from the Economy Prediction System (EPS) Database.

\section{Variable definitions}

\section{Dependent variables}

Total factor productivity (TFP). TFP has been a core measure of input-output efficiency, but there has been a lack of academic consensus on how to measure TFP (Syverson 2011). Since non-parametric methods such as data envelopment analysis may not avoid simultaneity and selection bias problems (Gatto et al. 2011), parametric methods such as stochastic frontier analysis rely heavily on the assumption of TFP distribution (Xiao et al. 2021). In light of these deficiencies, we employ two semiparametric methods proposed by Levinsohn and Petrin (2003) and Olley and Pakes (1996), called LP and OP methods, respectively, are the most widely used to measure enterprises' TFP (Ai et al. 2020; Peng et al. 2021). The LP method is an improvement of the OP method due to its unbiased consistent estimation results and its superiority in mitigating both the endogenous problems and sample loss (Cai and Ye 2020). Therefore, in the following analysis, only the enterprises' TFP estimated by LP method is analyzed, and the enterprises' TFP obtained by the OP method will be used as the benchmark regression robustness test.

\section{Independent variables}

Environmental regulation $(E R)$. At present, there is no unified standard on the measurement of environmental regulation intensity in academia. In order to further discuss the impact of environmental regulation on enterprise's TFP, this paper needs to construct appropriate environmental regulation variable. The existing research measures environmental regulation are usually based on pollution intensity (Ren et al. 2018), pollution control cost (Wang and Shen 2016), operating cost of pollution control facilities (Becker et al. 2013), the number of environmental protection personnel (Zhou et al. 2017), and the synthetic index of environmental regulation (Ai et al. 2020), these indicators often focus on one aspect of government environmental governance, while China's environmental regulation means include both economic means and legal and administrative means. Therefore, the above indicators are difficult to measure the overall appearance of government's environmental governance, and there is obvious endogeneity between these indicators and economic development (Cai et al. 2016). As such, they may suffer from severe measurement errors and simultaneity bias (Yang and Song 2019; Peng et al. 
2021). The government work report is an outline for the administration and implementation of decisions and resolutions of organs of power in accordance with the law, it is a programmatic document to guide the government work, so it can reflect the government's environmental governance policy comprehensively. The proportion of environment-related vocabulary in a city's government annual work report is commonly used by the public to measure the amount of actual effort that local government has exerted in environmental governance (Chen et al. 2018). In addition, since the government work report is often prepared at the beginning of the year, it is not affected by the economic development of that year, which can effectively alleviate the endogenous problems (Yang and Song 2019).

For this reason, referring to Chen et al. (2018), this paper selects the frequency of environment-related vocabulary in each city's annual government work report as a proportion of the total frequency of vocabulary as a proxy variable for environmental regulation.[5] But Chen et al. (2018) only selected five environment-related vocabulary, including "environment", "energy consumption", "pollution", "emission reduction" and "environmental protection", the vocabulary of environmental category is not specific. Compared with Chen et al. (2018), this paper chooses a richer vocabulary, which can more comprehensively reflects the strength of government's environmental governance.[6]

However, the above method is not so perfect, because we can not rule out the influence of vocabulary such as "political ecology", "vicious cycle" which are not related to environmental protection.

Therefore, we employ the total number of words in the environment-related paragraphs as a proportion of the total number of words in that annual government work report (ER2) as a robustness test. Furthermore, the environmental-related vocabulary selected in this paper is subjective and random, in order to avoid estimation bias due to subjectivity and randomness, based on the original environmental-related vocabulary, this paper deleted four vocabulary with low frequency, such as "cycle", "sustainable development", "greening", "particulate matter", to construct the independent variable $E R 3$ as the robustness test.

The specific construction steps of environmental regulation indicators in this research are as follows: First, manual collection of government work reports from prefecture-level and above cities in China for 2010-2018; Secondly, read each government work report in order to pick out the paragraphs devoted to the ecological environment; Finally, use Python 3.8 to calculate ER, ER2 and ER3 according to environmental-related text.

\section{Moderators}

Enterprises' bargaining power $(B P)$. There are few studies on enterprises' bargaining power, and most of them measure enterprises' bargaining power unilaterally by the amount of tax paid, the number of employees, and regulatory capture, and lack the organic integration of the three, thus failing to accurately characterize enterprises' bargaining power. Compared with other methods, the entropy evaluation method can eliminate the interference of human factors and make the evaluation results more scientific and reasonable. Therefore, we use the entropy evaluation method to compute a comprehensive score of enterprises' bargaining power, where corporate tax payments, number of employees, and regulatory 
capture all positively affect enterprises' bargaining power. Local government officials realize that political promotion mainly depends on economic performance (Zheng et al. 2015), so they often ignore the environmental violations of enterprises in exchange for local fiscal revenue, employment rate and economic growth (Jiang et al. 2014; Chen et al. 2018; Wang et al. 2018). Cai et al. (2011) found that travel and hospitality expenses under the administrative expense account in the financial statements of Chinese listed companies are often used by firms for bribes, seeking government support, etc., and that the item involves expenses for catering, entertainment, and other activities that are strongly associated with corrupt practices such as corporate bribery. And it has been shown that corrupt practices will reduce enterprises' TFP (Wu et al. 2017). Referring to Cai et al. (2011), this paper uses the sum of business entertainment fee and travel expenses to measure enterprises' regulatory capture behavior. Therefore, it is relatively reasonable and scientific to select the tax amount, the number of employees and regulatory capture to synthesize the bargaining power index.

Corporate ownership structure (Soe), Soe is 1 if it is a state-owned enterprise, 0 otherwise.

Executive compensation incentives $(E C i)$, in this paper, the median of the executive compensation is used as the cut-off point, with the higher group assigns a value of 1 and the lower group assigns a value of 0 .

Enterprise pollution level $(P o l), P o l$ is 1 if it is a heavy-polluting enterprise, 0 otherwise. And the heavypolluting enterprises are defined according to the Guidelines for Environmental Information Disclosure of Listed Companies issued by the Ministry of Environmental Protection in 2010 and the industry classification of China Securities Regulatory Commission in 2012.[7]

Political constraints $(P C)$, the sample cities are divided into provincial capital cities and non-provincial capital cities, and $P C$ is 1 if it is a provincial capital city, and 0 otherwise.

\section{Control variables}

To control for other important factors affecting enterprises' TFP, the control variables are selected mainly at the region- and firm-level in this paper. Referring to Hou et al. (2020), the region-level control variables mainly include GDP per capita $(P g d p)$, industrial structure (Indu), population density $(P d e n)$, foreign direct investment $(F D I)$ and science expenditure scale $(S C i)$ to control the effects of economic development level, industrial structure characteristics, human activity scale, foreign trade and R\&D investment on enterprises' TFP. Referring to Ai et al. (2020) and Feng et al. (2020), this paper also incorporates firm size (Size), asset liability ratio $(L e v)$, firm performance $(R o a)$, capital labor density $(C D)$, ratio of fixed assets $(F R)$, and corporate governance, respectively. Among them, the variables of corporate governance level include the shareholding ratio of the largest shareholder (Shrcr), the duality of chairman and general manager (Duality), and the proportion of independent directors (Bodind).

\section{Model specification and model approach}

In order to examine the causal influence of environmental regulation on enterprises' TFP, we construct the following model: 
Among them, where $T F P_{i t}$ is the TFP of firm $i$ in year $t, E R_{m t}$ is the environmental regulation intensity of city $m$ in year $t, X_{i m t}$ is a set of control variables that include firm- and region-level; $\mu_{i} v_{t}$ and $\gamma_{j}$ represent the firm, year and industry fixed effect, respectively; $\varepsilon_{i t}$ is the random error term.

To examine the moderating role of enterprises' bargaining power, the following model is designed in this paper:

$$
T F P_{i t}=\alpha+\beta_{1} E R_{n t}+\beta_{2} B P_{i t}+\beta_{3} E R_{n t} * B P_{i t}+\beta_{4} X_{i n t}+\mu_{i}+\lambda_{t}+\gamma_{j}+\varepsilon_{i t}
$$

$B P_{i t}$ is the bargaining power of enterprise $i$ in year $t$.

In order to explore the boundary when environmental regulation works, the following model is formalized:

$$
T F P_{i t}=\alpha+\beta_{1} E R_{m t}+\beta_{2} E R_{m t} * \text { Moderatorimt }+\beta_{3} X_{i m t}+\mu_{i}+\lambda_{t}+\gamma_{j}+\varepsilon_{i t}
$$

Moderator $_{i m t}$ is the four moderating variables of heterogeneity analysis.

[5] Among them, the government work reports come from: http://www.drcnet.com.cn/www/int/.

[6] Specifically, the environmental terms selected in this paper include: pollution, emission reduction, ecology, PM2.5, pm2.5, haze, emission, air, pm10, PM10, green, environmental protection, energy conservation, dust, ammonia nitrogen, soot, atmosphere, sulfur dioxide, sewage, SO2, water conservation, nitrogen and oxygen, chemical oxygen demand, COD, energy consumption, forest coverage, low carbon, pollution control, wastewater, waste gas, carbon dioxide, consumption reduction, cycle, sustainable development, greening, particulate matter.

[7] Heavy-polluting industries specifically includes thermal power, iron and steel, cement, electrolytic aluminum, coal, metallurgy, chemical, petrochemical, building materials, paper, brewing, pharmaceutical, fermentation, textile, tannery and mining and other 16 types of industries.

\section{Empirical Results}

\section{Descriptive statistics}

The definition of variables and descriptive statistics are exhibited in Table 1. The mean value and median of TFP_Ip are 7.999 and 7.924 respectively, the mean value and median of TFP_op are 3.572 and 3.492 respectively. Comparing with the results of Cai and Ye (2020) (the mean value of TFP_Ip and TFP_op are 8.556 and 4.081 respectively), the mean value of TFP_I $p$ and TFP_op in this paper is relatively small, which may be due to the disappearance of China's "demographic dividend" in recent years, resulting in the decline of enterprises' TFP. The mean value and standard deviation of $E R$ (unit is \%) are 0.829 and 
0.698 respectively, which indicates that the environmental regulation intensity is slightly different among cities.

Table 1 Variable definitions and descriptive statistics 


\begin{tabular}{|c|c|c|c|c|c|}
\hline & Code & Definitions of variables & Mean & Std.dev & Median \\
\hline \multirow[t]{2}{*}{ Dependent Variables } & TFP_Ip & $\begin{array}{l}\text { TFP calculated using the LP } \\
\text { method }\end{array}$ & 7.999 & 0.934 & 7.924 \\
\hline & TFP_op & $\begin{array}{l}\text { TFP calculated using the OP } \\
\text { method }\end{array}$ & 3.572 & 0.698 & 3.492 \\
\hline \multirow[t]{5}{*}{ Moderating Variables } & $\mathrm{BP}$ & $\begin{array}{l}\text { Bargaining power of } \\
\text { enterprises }\end{array}$ & 0.017 & 0.024 & 0.009 \\
\hline & Soe & $\begin{array}{l}1 \text { means the state is the } \\
\text { ultimate controller, } 0 \text { otherwise }\end{array}$ & 0.333 & 0.471 & 0 \\
\hline & Eci & $\begin{array}{l}1 \text { for higher than the median } \\
\text { of executive compensation, } 0 \\
\text { otherwise }\end{array}$ & 0.500 & 0.500 & 0 \\
\hline & Pol & $\begin{array}{l}1 \text { for heavy-polluting } \\
\text { enterprises, } 0 \text { otherwise }\end{array}$ & 0.383 & 0.486 & 0 \\
\hline & PC & $\begin{array}{l}1 \text { for provincial capital cities, } 0 \\
\text { otherwise }\end{array}$ & 0.455 & 0.498 & 0 \\
\hline \multirow[t]{3}{*}{ Independent Variables } & ER & $\begin{array}{l}\text { Proportion of environmental- } \\
\text { related vocabulary }\end{array}$ & 0.829 & 0.229 & 0.840 \\
\hline & ER2 & $\begin{array}{l}\text { Proportion of words in } \\
\text { environmental-related } \\
\text { paragraphs }\end{array}$ & 6.435 & 2.748 & 6.360 \\
\hline & ER3 & $\begin{array}{l}\text { Proportion of environmental- } \\
\text { related vocabulary }\end{array}$ & 0.755 & 0.216 & 0.740 \\
\hline \multirow[t]{5}{*}{ Regional Characteristics } & Pgdp & Natural log of GDP per capita & 11.312 & 0.524 & 11.380 \\
\hline & Indu & $\begin{array}{l}\text { Added value of tertiary } \\
\text { industry/GDP }\end{array}$ & 43.580 & 10.673 & 45.310 \\
\hline & Pden & $\begin{array}{l}\text { Total population at the end of } \\
\text { the year/Urban administrative } \\
\text { area }\end{array}$ & 0.084 & 0.057 & 0.072 \\
\hline & FDI & $\begin{array}{l}\text { Natural log of foreign direct } \\
\text { investment }\end{array}$ & 14.038 & 1.728 & 14.447 \\
\hline & Sci & Science expenditure/GDP & 0.006 & 0.005 & 0.004 \\
\hline \multirow[t]{5}{*}{ Firm Characteristics } & Size & Natural log of assets & 21.973 & 1.101 & 21.858 \\
\hline & Lev & Total liabilities/total assets & 0.415 & 0.205 & 0.404 \\
\hline & Roa & Net profits/total assets & 3.737 & 5.540 & 3.557 \\
\hline & Duality & $\begin{array}{l}1 \text { for duality of CEO and chair } \\
\text { of the board, } 0 \text { otherwise }\end{array}$ & 0.274 & 0.446 & 0 \\
\hline & Shrcr & Shareholding of the largest & 34.262 & 14.610 & 32.093 \\
\hline
\end{tabular}


shareholder

\begin{tabular}{|lllll|}
\hline Bodind & $\begin{array}{l}\text { Proportion of independent } \\
\text { directors }\end{array}$ & 0.374 & 0.052 & 0.333 \\
\hline CD & $\begin{array}{l}\text { Net fixed assets/Number of } \\
\text { employees }\end{array}$ & 45.917 & 67.280 & 26.401 \\
\hline FR & Net fixed assets/total assets & 0.212 & 0.154 & 0.182 \\
\hline 14,110 & & & & \\
\hline
\end{tabular}

\section{Benchmark regression}

Table 2 exhibits the benchmark regression results. When we only control the firm characteristics, $E R$ is significantly positive at the level of $5 \%$. When no control variable is controlled, or only the regional characteristics are controlled, or all control variables are included, $E R$ is significantly positive at the level of $1 \%$. With the incorporation of more control variables, its value and significance fluctuate a little. Taking the full model as an example, on average, environmental regulation increases enterprises' TFP by $4 \%$, and Hypothesis 1 is verified. However, compared with the policy effect of SO2 emission trading pilot to improve the enterprises' TFP by 23\% (Feng et al. 2020), the magnitude of increase is far from adequate and provides greater space and room for improvement.

Table 2 Benchmark regression results

\begin{tabular}{|lllll|}
\hline & $(1)$ & $(2)$ & $(3)$ & $(4)$ \\
\hline ER & $0.065^{\star \star \star}$ & $0.033^{\star \star}$ & $0.078^{\star \star \star}$ & $0.040^{\star \star \star}$ \\
\hline Firm characteristics & No & Yes & No & Yes \\
\hline Regional characteristics & No & No & Yes & Yes \\
\hline Firm fixed effect & Yes & Yes & Yes & Yes \\
\hline Year fixed effect & Yes & Yes & Yes & Yes \\
\hline Industry fixed effect & Yes & Yes & Yes & Yes \\
\hline R__within & 0.215 & 0.543 & 0.217 & 0.544 \\
\hline Obs & 14,110 & 14,110 & 14,110 & 14,110 \\
\hline
\end{tabular}

Note: T values are presented in parentheses. ${ }^{* * *},{ }^{* *}$, and * are statistically significant at the $1 \%, 5 \%$, and $10 \%$ levels, respectively.

\section{Robust tests}


To ensure that the benchmark regression results are robust, a series of robustness tests are conducted in this paper. As exhibited in column (1) of Table 3, we use the TFP obtained by OP method as the dependent variable, the value and significance of $E R$ do not differ significantly from the result of the benchmark regression (see column (4) of Table 2). Column (2) of Table 3, we employ ER2 as the independent variable. Column (3) of Table 3,ER3 as the independent variable. Further, this paper applies robust standard error corrected for heteroskedasticity, and the result is exhibited in column (4) of Table 3. The above robustness test results all present that the benchmark regression results are robust.

Table 3 Robust tests

\begin{tabular}{|lllll|}
\hline & $(1)$ & $(2)$ & $(3)$ & $(4)$ \\
\hline ER & $0.036^{\star \star \star}$ & $0.004^{\star \star \star}$ & $0.040 \star \star \star$ & $0.040 \star \star \star$ \\
\hline Firm characteristics & Yes & Yes & Yes & Yes \\
\hline Regional characteristics & Yes & Yes & Yes & Yes \\
\hline Firm fixed effect & Yes & Yes & Yes & Yes \\
\hline Year fixed effect & Yes & Yes & Yes & Yes \\
\hline Industry fixed effect & Yes & Yes & Yes & Yes \\
\hline R ${ }^{2}$ _within & 0.244 & 0.544 & 0.544 & 0.544 \\
\hline Obs & 14,110 & 14,110 & 14,110 & 14,110 \\
\hline
\end{tabular}

Note: T values are presented in parentheses. ***, **, and * are statistically significant at the $1 \%, 5 \%$, and $10 \%$ levels, respectively.

\section{The moderating role of enterprises' bargaining power}

The moderating effect of enterprises' bargaining power is exhibited in Table 4. Regardless of whether the region-level or firm-level characteristics have been controlled, $E R^{\star} B P$ remains positively pronounced at the level of $5 \%$. Therefore, we confirm that enterprises' bargaining power has a significant negative moderating effect on the relationship between environmental regulation and enterprises' TFP. These results support Hypothesis 2. The reason is that enterprises take their contribution to local economic growth and officials performance evaluation, as "chips" to bargain with local government, so as to exempt from environmental regulation (Feng et al. 2020).

Table 4 Moderating effect of enterprises' bargaining power 


\begin{tabular}{|c|c|c|c|c|}
\hline & $(1)$ & $(2)$ & (3) & (4) \\
\hline \multirow[t]{2}{*}{ ER } & $0.089 * * *$ & $0.055^{\star \star \star}$ & $0.095^{\star \star \star}$ & $0.059 * * \star$ \\
\hline & $(4.385)$ & (3.375) & $(4.688)$ & $(3.646)$ \\
\hline \multirow[t]{2}{*}{ BP } & $11.949 * \star \star$ & $3.707 * \star \star$ & $11.823^{\star \star \star}$ & $3.591^{\star * *}$ \\
\hline & $(19.625)$ & $(7.367)$ & $(19.375)$ & $(7.122)$ \\
\hline \multirow[t]{2}{*}{$E R * B P$} & $-1.423^{\star *}$ & $-1.167 * \star$ & $-1.353^{\star *}$ & $-1.086^{\star *}$ \\
\hline & $(-2.233)$ & $(-2.296)$ & $(-2.122)$ & $(-2.134)$ \\
\hline Firm characteristics & No & Yes & No & Yes \\
\hline Regional characteristics & No & No & Yes & Yes \\
\hline Firm fixed effect & Yes & Yes & Yes & Yes \\
\hline Year fixed effect & Yes & Yes & Yes & Yes \\
\hline Industry fixed effect & Yes & Yes & Yes & Yes \\
\hline $\mathrm{R}^{2}$ _within & 0.287 & 0.548 & 0.288 & 0.548 \\
\hline Obs & 14,110 & 14,110 & 14,110 & 14,110 \\
\hline
\end{tabular}

Note: T values are presented in parentheses. ***, **, and * are statistically significant at the $1 \%, 5 \%$, and $10 \%$ levels, respectively.

\section{Further analysis}

The impact of environmental regulation on enterprises' TFP varies with different enterprises, industries and regions (Cai and Ye 2020). Accordingly, the paper will next discuss the causal relationship between environmental regulation and enterprises' TFP in terms of firm-, industry-, and region-level heterogeneity.

\section{The heterogeneity of corporate ownership structure}

As demonstrated in column (1) of Table 5, whether for state-owned enterprises or non-state-owned enterprises, environmental regulation significantly improves enterprises' TFP, but it has a greater effect on state-owned enterprises (coefficient $=0.058, t=2.286$ ). One possible reason is that state-owned enterprises undertake important political tasks for the state and are also politically sheltered by the government (Tang et al. 2018). Therefore, state-owned enterprises are more likely to enjoy preferential policies from the government, such as government subsidies and credit preferences, and are less likely to be adversely affected by environmental regulation policies (Peng et al. 2021). Accordingly, compared with non-state-owned enterprises, state-owned enterprises are more motivated to improve TFP.

\section{The heterogeneity of executive compensation incentive}


As shown in column (2) of Table 5, environmental regulation significantly increases enterprises' TFP with lower executive compensation (coefficient $=0.066, t=3.754$ ) compared to firms with higher executive compensation (coefficient $=0.011, t=608$ ). The possible reason is that the excessive remuneration of senior executives has caused disputes within the company, which leads to the increase of operating costs and the reduction of dividend, even reduce the R\&D innovation ability of the enterprise (Yanadori and Cui 2013), which will further have a negative impact on enterprises' TFP (Faleye et al. 2011).

\section{The heterogeneity of enterprise pollution levels}

As we can see in column (3) of Table 5, environmental regulation significantly improves enterprises' TFP, whether for heavy-polluting industries (coefficient $=0.056, t=2.771$ ) or non-heavy-polluting industries (coefficient $=0.029, t=1.675$ ), but the effect is greater for heavy-polluting enterprises. A possible reason is that heavy-polluting enterprises, as the main polluters of the environment, are more likely to attract the attention of environmental regulatory authorities (Ren et al. 2021). Therefore, heavy-polluting enterprises are more affected by environmental regulation, which need to improve their TFP to cater to the environmental regulation policies of local government.

\section{The heterogeneity of political constraints}

As exhibited in column (4) of Table 5, environmental regulation has a greater impact on enterprises' TFP located in provincial capitals (coefficient $=0.047, t=2.299$ ) compared to those located in non-capital cities (coefficient=0.035, $t=2.021$ ). This is not difficult to understand. On the one hand, the economic development level of provincial capital is often higher, and its industrial structure is also relatively reasonable. Local government can provide good development environment and preferential policies for companies. On the other hand, the political constraints of provincial capitals tend to be stronger, local government's environmental governance activities may be subject to stronger supervision by the superior government, and the social development goals of such cities are often more diversified compared to the single goal of economic development and securing fiscal revenues. Thus environmental quality preferences may be greater in such cities, compared with other cities, the environmental regulation intensity of provincial capital cities is often greater, and more stringent environmental regulation will help improve enterprises' TFP (Albrizio et al. 2017; Ai et al. 2020).

Table 5 Heterogeneity analysis 


\begin{tabular}{|c|c|c|c|c|}
\hline & (1) & (2) & (3) & (4) \\
\hline \multirow[t]{2}{*}{ ER } & $0.035^{\star \star}$ & $0.066^{\star * *}$ & $0.029 *$ & $0.035^{\star \star}$ \\
\hline & $(2.110)$ & $(3.754)$ & $(1.675)$ & $(2.021)$ \\
\hline \multirow[t]{2}{*}{ ER*Soe } & 0.015 & & & \\
\hline & $(0.555)$ & & & \\
\hline \multirow[t]{2}{*}{ Test ER+ER*Soe } & $0.058^{\star *}$ & & & \\
\hline & $(2.286)$ & & & \\
\hline \multirow[t]{2}{*}{ ER*Eci } & & $-0.055^{\star \star}$ & & \\
\hline & & $(-2.328)$ & & \\
\hline \multirow[t]{2}{*}{ Test ER+ER*Eci } & & 0.011 & & \\
\hline & & $(0.608)$ & & \\
\hline \multirow[t]{2}{*}{ ER*Pol } & & & 0.027 & \\
\hline & & & $(1.043)$ & \\
\hline \multirow[t]{2}{*}{ Test ER+ER*Pol } & & & $0.056 * \star \star *$ & \\
\hline & & & $(2.771)$ & \\
\hline \multirow[t]{2}{*}{$E R * P C$} & & & & 0.011 \\
\hline & & & & $(0.425)$ \\
\hline \multirow[t]{2}{*}{ Test ER+ER*PC } & & & & $0.047^{\star \star *}$ \\
\hline & & & & $(2.299)$ \\
\hline Firm characteristics & Yes & Yes & Yes & Yes \\
\hline Regional characteristics & Yes & Yes & Yes & Yes \\
\hline Firm fixed effect & Yes & Yes & Yes & Yes \\
\hline Year fixed effect & Yes & Yes & Yes & Yes \\
\hline Industry fixed effect & Yes & Yes & Yes & Yes \\
\hline $\mathrm{R}^{2}$ _within & 0.544 & 0.544 & 0.544 & 0.544 \\
\hline Obs & 14,110 & 14,110 & 14,110 & 14,110 \\
\hline
\end{tabular}

Note: T values are presented in parentheses. ${ }^{* \star}$, $* \star$, and * are statistically significant at the $1 \%, 5 \%$, and $10 \%$ levels, respectively. 


\section{Conclusions And Policy Implications}

Under the background of severe environmental pollution and increasing resource environmental constraints, can environmental regulation achieve a win-win situation of environmental protection and high-quality economic development? What is the role of enterprises' bargaining power in the relationship between environmental regulation and enterprises' TFP? Based on a sample of 14,110 firm-year observations in China from 2010 to 2018, we find that: 1) Environmental regulation significantly improves enterprises' TFP, which is still true after a series of robustness tests; 2) Enterprises' bargaining power significantly weakens the effect of environmental regulation on enterprises' TFP; 3) Compared with nonstate-owned enterprises, environmental regulation has a greater impact on state-owned enterprises' TFP; compared with enterprises with higher executive compensation, environmental regulation significantly improves the enterprises' TFP with lower executive compensation; for heavy-polluting industries and enterprises headquartered in high political constraints areas, the impact of environmental regulation on enterprises' TFP is more pronounced.

Our research contributes to the understanding of the conditions for enterprises to improve TFP from the perspective of government's environmental governance. First, in view of the debate about whether the Porter hypothesis is established in the academic circles, this paper systematically tests the impact of environmental regulation on enterprises' TFP, and provides China's Micro evidence for Porter hypothesis. Second, the existing literature on the measurement of environmental regulation, such as environmental tax (Xie et al. 2017), pollution control cost (Wang and Shen 2016), the number of environmental protection personnel (Zhou et al. 2017), but these indicators can easily lead to endogenous problems and can not fully reflect the government's environmental governance behavior. In addition, different from the previous literature which only used enterprises' total output to measure enterprises' bargaining power (Feng et al. 2020), this paper measures enterprises' bargaining power from a more comprehensive perspective, which makes the empirical results more convincing.

Apart from its theoretical contributions, our research also provides practical guidance for China as well as for other emerging economies. First, considering that there is still a lot of room to improve enterprises' TFP, the central government should further increase the environmental governance, in particular, environmental performance should be incorporated in the performance appraisal of local government officials to weaken the negative influence of enterprises' bargaining power. Second, the heterogeneous results suggest that the environmental policy of central government should avoid one-size-fits-all environmental regulation. Specifically, as the effect of environmental regulation on state-owned enterprises is greater than that of non-state-owned enterprises, thus the government can consider giving some policy support to non-state-owned enterprises; since excessive executive compensation does not enhance enterprises' TFP, appropriate reductions in executive compensation may be considered; it is necessary to strengthen the environmental regulation intensity for non-heavy-polluting enterprises and enterprises in non-provincial capital cities. 
Frankly speaking, our results are subject to some limitations. Firstly, for the heterogeneity analysis, this paper does not consider comprehensively, the follow-up research can start from more levels of heterogeneity. Secondly, there does not exist a consensus on how to measure enterprises' bargaining power. Based on the existing literature, this paper uses the entropy method to calculate enterprises' bargaining power, and the results are relatively objective and scientific. Thirdly, following recent literature (e.g., He et al. 2020), future research can explore this issue from the perspective of political economics such as political incentives.

\section{Declarations}

Acknowledgements: We would like to thank the editor and the anonymous referees for their valuable comments on this paper.

Author contributions: Shuwang Yang puts forward the idea and provides fund support, designs the study, and reviews the manuscript and is a major contributor in writing the manuscript. Chao Wang designs the study, performs the experiments and is a major contributor in writing the manuscript. Hao Zhang reviews the manuscript and edits the manuscript. Tingshuai Lu collects data. Yang Yi edits the manuscript. All authors approve to the final manuscript and consent to publish. All authors contribute to the study conception and design.

Funding: This work is financially supported by National Natural Science Foundation of China (Grant No: 72004210).

Data availability: The datasets used and/or analyzed during the current study are available from the corresponding author on reasonable request.

Conflict of Interest: Authors declare that they have no conflict of interest.

Ethical approval: This article does not contain any studies with human participants or animals performed by any of the authors.

Consent to participate: All authors participated in this article.

Consent for publication: All authors have given consent to the publication of this article.

\section{References}

1. Ai HS, Hu SL, Li K, Shao S (2020) Environmental regulation, total factor productivity, and enterprise duration: Evidence from China. Bus Strateg Environ 29:2284-2296

2. Albrizio S, Kozluk T, Zipperer V (2017) Environmental policies and productivity growth: Evidence across industries and firms. J Environ Econ Manage 81:209-226 
3. Bai JH, Lu JY, Li SJ (2019) Fiscal pressure, tax competition and environmental pollution. Environ Resour Econ 73:431-447

4. Becker RA (2011) Local environmental regulation and plant-level productivity. Ecol Econ 70:25162522

5. Becker RA, Pasurka C, Shadbegian RJ (2013) Do environmental regulations disproportionately affect small businesses? Evidence from the pollution abatement costs and expenditures survey. J Environ Econ Manage 66:523-538

6. Cai HB, Fang HM, Xu LC (2011) Eat, drink, firms, government: An investigation of corruption from the entertainment and travel costs of Chinese firms. J Law Econ 54:55-78

7. Cai WG, Ye PY (2020) How does environmental regulation influence enterprises' total factor productivity? A quasi-natural experiment based on China's new environmental protection law. J Clean Prod 276:124105

8. Cai XQ, Lu Y, Wu MQ, Yu LH (2016) Does environmental regulation drive away inbound foreign direct investment? Evidence from a quasi-natural experiment in China. J Dev Econ 123:73-85

9. Chang L, Li WJ, Lu XY (2015) Government engagement, environmental policy, and environmental performance: Evidence from the most polluting Chinese listed firms. Bus Strateg Environ 24:1-19

10. Chen YY, Ebenstein A, Greenstone M, Li HB (2013a) Evidence on the impact of sustained exposure to air pollution on life expectancy from China's Huai River policy. Proc Natl Acad Sci U S A 110:1293612941

11. Chen YY, Jin GZ, Kumar N, Shi G (2013b) The promise of Beijing: Evaluating the impact of the 2008 Olympic Games on air quality. J Environ Econ Manage 66:424-443

12. Chen Z, Kahn ME, Liu Y, Wang Z (2018) The consequences of spatially differentiated water pollution regulation in China. J Environ Econ Manage 88:468-485

13. Child J, Lu Y, Tsai T (2007) Institutional entrepreneurship in building an environmental protection system for the People's Republic of China. Organ Stud 28:1013-1034

14. Du XQ, Jian W, Zeng Q, Du YJ (2014) Corporate environmental responsibility in polluting industries: Does religion matter? J Bus Ethics 124:485-507

15. Faleye O, Hoitash R, Hoitash U (2011) The costs of intense board monitoring. J Financ Econ 101:160-181

16. Feng YH, Chen SL, Failler P (2020) Productivity effect evaluation on market-type environmental regulation: A case study of SO2 emission trading pilot in China. Int J Environ Res Public Health 17:8027

17. Gatto M, Liberto AD, Petraglia C (2011) Measuring productivity. J Econ Surv 25:952-1008

18. He GJ, Fan MY, Zhou MG (2016) The effect of air pollution on mortality in China: Evidence from the 2008 Beijing Olympic Games. J Environ Econ Manage 79:18-39

19. He GJ, Wang SD, Zhang B (2020) Watering down environmental regulation in China*. Q J Econ $135: 2135-2185$ 
20. Hou BQ, Wang B, Du MZ, Zhang N (2020) Does the SO2 emissions trading scheme encourage green total factor productivity? An empirical assessment on China's cities. Environ Sci Pollut Res 27:63756388

21. Jiang LL, Lin C, Lin P (2014) The determinants of pollution levels: Firm-level evidence from Chinese manufacturing. J Comp Econ 42:118-142

22. Jiang QS, Yang SW, Tang PC, Bao L (2020) Promoting the polluters? The competing objectives of energy efficiency, pollutant emissions, and economic performance in Chinese municipalities. Energy Res Soc Sci 61:101365

23. Jin Y, Henrik A, Zhang S (2016) Air pollution control policies in China: A retrospective and prospects. Int J Environ Res Public Health 13:1219

24. Lanoie P, Patry M, Lajeunesse R (2008) Environmental regulation and productivity: testing the Porter hypothesis. J Prod Anal 30:121-128

25. Levinsohn J, Petrin A (2003) Estimating production functions using inputs to control for unobservables. Rev Econ Stud 70:317-341

26. Li L, Liu XM, Ge JJ, Chu XH, Wang J (2019) Regional differences in spatial spillover and hysteresis effects: A theoretical and empirical study of environmental regulations on haze pollution in China. $J$ Clean Prod 230:1096-1110

27. Liu MD, Shadbegian R, Zhang B (2017) Does environmental regulation affect labor demand in China? Evidence from the textile printing and dyeing industry. J Environ Econ Manage 86:277-294

28. Liu MD, Tan RP, Zhang B (2021) The costs of "blue sky": Environmental regulation, technology upgrading, and labor demand in China. J Dev Econ 150:104610

29. Noailly J, Smeets R (2015) Directing technical change from fossil-fuel to renewable energy innovation: An application using firm-level patent data. J Environ Econ Manage 72:15-37

30. Olley GS, Pakes A (1996) The dynamics of productivity in the telecommunications equipment industry. Econometrica 64:1263-1297

31. Peng JY, Xie R, Ma CB, Fu Y (2021) Market-based environmental regulation and total factor productivity: Evidence from Chinese enterprises*. Econ Model 95:394-407

32. Porter ME, Linde C (1995) Toward a new conception of the environment-competitiveness relationship. J Econ Perspect 9:97-118

33. Ran R (2017) Understanding blame politics in China's decentralized system of environmental governance: Actors, strategies and context. China Q 231:634-661

34. Ren SG, Li XL, Yuan BL, Li DY, Chen XH (2018) The effects of three types of environmental regulation on eco-efficiency: A cross-region analysis in China. Bus Strateg Environ 173:245-255

35. Ren SG, Wang Y, Hu YC, Yan J (2021) CEO hometown identity and firm green innovation. Bus Strateg Environ 30:756-774

36. Rivers N (2013) Renewable energy and unemployment: A general equilibrium analysis. Resour Energy Econ 35:467-485 
37. Syverson C (2011) What Determines Productivity? J. Econ. Lit. 49, 326 - 65

38. Tang P, Jiang Q, Mi L (2021) One-vote veto: The threshold effect of environmental pollution in China's economic promotion tournament. Ecol Econ 185:107069

39. Tang PC, Yang SW, Boehe D (2018) Ownership and corporate social performance in China: Why geographic remoteness matters. J Clean Prod 197:1284-1295

40. Tang PC, Yang SW, Shen J, Fu SK (2018) Does China's low-carbon pilot programme really take off? Evidence from land transfer of energy-intensive industry. Energy Policy 114:482-491

41. Vanhamme J, Lindgreen A, Reast J, van Popering N (2012) To do well by doing good: Improving corporate image through cause-related marketing. J Bus Ethics 109:259-274

42. Wang C, Yang Y, Zhang JJ (2015) China's sectoral strategies in energy conservation and carbon mitigation. Clim Policy 15:S60-S80

43. Wang HS, Yang GQ, Xiao OY, Qin JY (2021) Does central environmental inspection improves enterprise total factor productivity? The mediating effect of management efficiency and technological innovation. Environ Sci Pollut Res 28:21950-21963

44. Wang Q, Ren SG, Hou Y (2020) Atmospheric environmental regulation and industrial total factor productivity: the mediating effect of capital intensity. Environ Sci Pollut Res 27:33112-33126

45. Wang RX, Wijen F, Heugens P (2018) Government's green grip: Multifaceted state influence on corporate environmental actions in China. Strateg Manage J 39:403-428

46. Wang Y, Shen N (2016) Environmental regulation and environmental productivity: The case of China. Renew Sust Energ Rev 62:758-766

47. Wu SS, Li B, Nie QL, Chen C (2017) Government expenditure, corruption and total factor productivity. $\mathrm{J}$ Clean Prod 168:279-289

48. Xiao J, Li G, Zhu B, Xie L (2021) Evaluating the impact of carbon emissions trading scheme on Chinese firms' total factor productivity. J Clean Prod 306:127104

49. Xie RH, Yuan YJ, Huang JJ (2017) Different types of environmental regulations and heterogeneous influence on "green" productivity: Evidence from China. Ecol Econ 132:104-112

50. Xu CG (2011) The fundamental institutions of China's reforms and development. J Econ Lit 49:1076-1151

51. Xu F, Yang M, Li QY, Yang XL (2020) Long-term economic consequences of corporate environmental responsibility: Evidence from heavily polluting listed companies in China. Bus Strateg Environ 29:2251-2264

52. Yanadori Y, Cui V (2013) Creating incentives for innovation? The relationship between pay dispersion in R\&D groups and firm innovation performance. Strateg Manage J 34:1502-1511

53. Yang CH, Tseng YH, Chen CP (2012) Environmental regulations, induced R\&D, and productivity: Evidence from Taiwan's manufacturing industries. Resour Energy Econ 34:514-532

54. Yang QY, Song DY (2019) How does environmental regulation break the resource curse: Theoretical and empirical study on China. Resour Policy 64:101480 
55. Zheng W, Chen P (2020) The political economy of air pollution: Local development, sustainability, and political incentives in China. Energy Res Soc Sci 69:101707

56. Zheng WT, Singh K, Mitchell W (2015) Buffering and enabling: The impact of interlocking political ties on firm survival and sales growth. Strateg Manage J 36:1615-1636

57. Zhou Y, Zhu SJ, He CF (2017) How do environmental regulations affect industrial dynamics? Evidence from China's pollution-intensive industries. Habitat Int 60:10-18

\section{Figures}

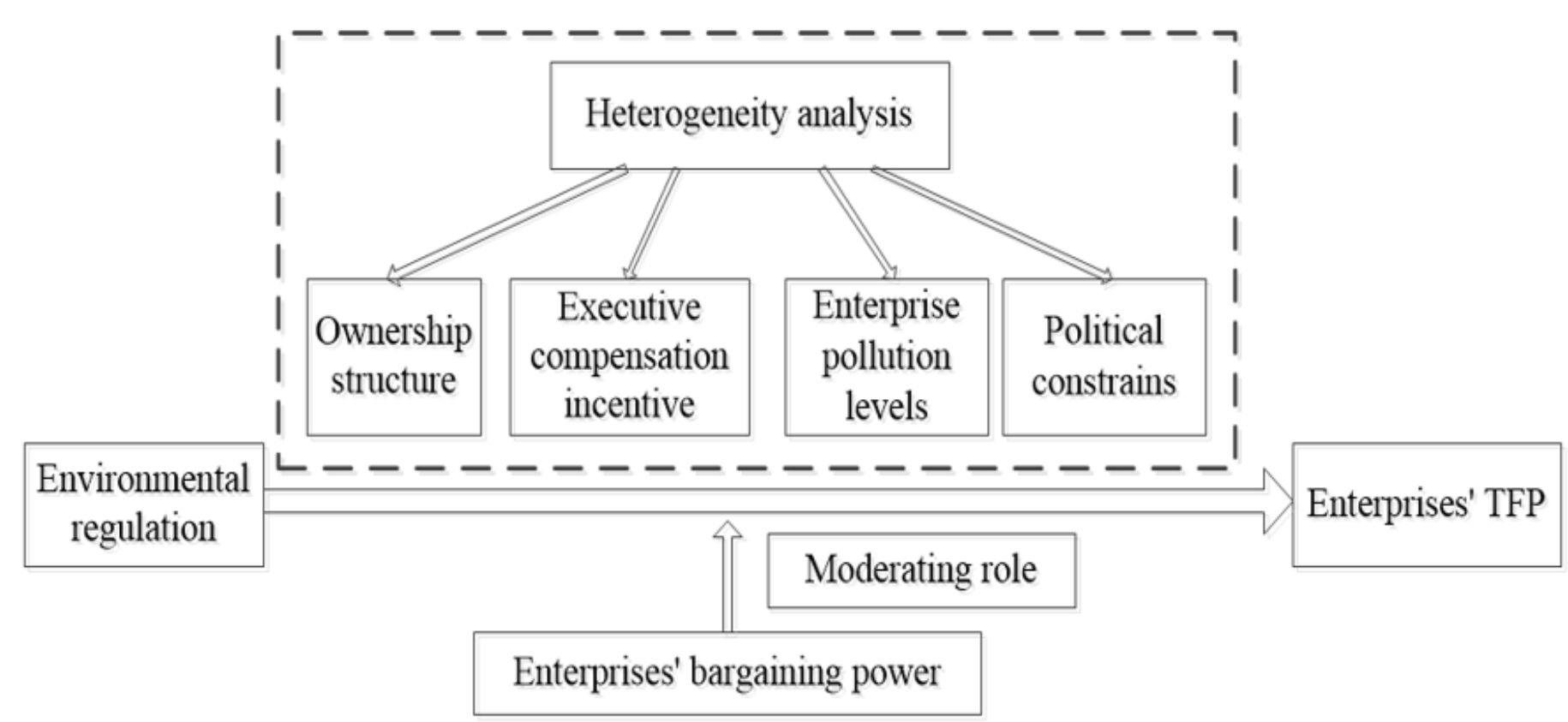

Figure 1

Conceptual framework 